9326

For submission to The Journal of Clinical Investigation

\title{
HIV Transcription is Induced in Dying Cells
}

\author{
Gayle E. Woloschak", Steven Schreck, "I John Panozzo, ${ }^{\ddagger}$ Chin-Mei Chang- \\ Liu, and Claudia R. Libertin ${ }^{\text {\$\$ }}$
}

${ }^{*}$ Center for Mechanistic Biology and Biotechnology, Argonne National

Laboratory, 9700 South Cass Avenue, Argonne, IL 60439-4833; ${ }^{\ddagger}$ Department of Pathology, \$ Department of Medicine, Loyola University Medical Center, 2160 South First Avenue, Maywood, IL 60153; "Department of Chemistry, University of South Carolina, Columbia, SC 29208.

Running Title: HIV is induced in dying cells

Key Words: Apoptosis; DNA-damaging agent; HIV-LTR expression; radiation; stress response The submitted manuscript has been authored
by a contractor of the U.S. Government
under contract No. W-3t-109-ENG-38.
Accordingiy. the U. S. Government retains a
nonexclusive. royalty.free ficense to publish
or reproduce the published form of this
contribution. or allow others to do so. for
U. S. Government purposes.

Address correspondence to Dr. Gayle E. Woloschak, Center for Mechanistic Biology and Biotechnology, Argonne National Laboratory, Argonne, Illinois 60439. Phone: (708)252-3312; FAX: (708)252-3387; e mail: wolo@anlbem.bim.anl.gov. 
Abstract

Using HeLa cells stably transfected with an HIV-LTR-CAT ${ }^{1}$

construct, we demonstrated a peak in CAT induction that occurs in viable

(but not necessarily cell-division-competent) cells $24 \mathrm{~h}$ following exposure

to some cell-killing agents. $\gamma$ rays were the only cell-killing agent which

did not induce HIV transcription; this can be attributed to the fact that $\gamma$ -

ray-induced apoptotic death requires functional p53, which is not present

in HeLa cells. For all other agents, HIV-LTR induction was dose-

dependent and correlated with the amount of cell killing that occurred in

the culture.

\title{
DISCLAIMER
}

\begin{abstract}
This report was prepared as an account of work sponsored by an agency of the United States Government. Neither the United States Government nor any agency thereof, nor any of their employees, makes any warranty, express or implied, or assumes any legal liability or responsibility for the accuracy, completeness, or usefulness of any information, apparatus, product, or process disclosed, or represents that its use would not infringe privately owned rights. Reference herein to any specific commercial product, process, or service by trade name, trademark, manufacturer, or otherwise does not necessarily constitute or imply its endorsement, recommendation, or favoring by the United States Government or any agency thereof. The views and opinions of authors expressed herein do not necessarily state or reflect those of the United States Government or any agency thereof.
\end{abstract}

\footnotetext{
${ }^{1}$ Abbreviations used in this paper: HIV-LTR, human immunodeficiency virus long terminal repeat; CAT, chloramphenicol acetyl transferase.
} 


\section{DISCLAIMER}

Portions of this document may be illegible in electronic image products. Images are produced from the best available original document. 


\section{Introduction}

Valerie et al. (1) described the induction of transcription from the human immunodeficiency virus long terminal repeat (HIV-LTR) following exposure to DNA-damaging agents in HeLa cells stably transfected with a construct containing the chloramphenicol acetyl transferase (CAT) reporter gene driven by the HIV-LTR promoter. Since then, many reports have reproduced and expanded upon those findings (2-6), even demonstrating in vivo induction in transgenic mouse systems. Recent work from our laboratory has shown enhanced expression from the HIV promoter following exposure of cells to fission-spectrum neutrons at doses which also induce expression of apoptosisassociated genes (4). We set out in these experiments to determine whether this HIV-LTR induction was a consequence of DNA damage, as suggested by the initial reports, or whether it was associated with the onset of cell death in general (such as occurs during apoptosis or programmed cell death).

\section{Methods}

Cell Lines. HeLa cells stably transfected with HIV-LTR-CAT construct were generously provided by Dr. K. Valerie (3). Immediate cell death was determined by trypan blue dye exclusion. Colony forming cell assays (14 day) were performed as described $(4,7)$. 
CAT Assays. CAT assays were performed as previously desribed $(4,7)$.

Treatments. Equal numbers and concentrations of HeLa cells stably transfected with the HIV-LTR-CAT construct were exposed in triplicate to varying doses of electric current at the indicated voltages; electroporation was carried out in the presence of PBS. Cells were harvested $24 \mathrm{~h}$ following exposure and counted.

For UV exposures, HeLa cells stably transfected with the HIV-LTR-CAT construct were exposed to different doses (as indicated) of UVC (254 nm) germicidal lamp (General Electric GE 30T830W). The irradiations were at a distance of $55.6 \mathrm{~cm}$ from the source. The dose-rate for all UVC exposures was $\mathrm{Jm}^{-2} / \mathrm{sec}(7)$. The media were removed from the plates. Plates were washed once in PBS prior to UV exposure without plate covers. Cells were harvested 24-180 h following exposure. Equal numbers of viable cells were used in each CAT assay $(4,7)$. Conditions for other treatments are as defined in Table 1 and as defined $(4,7)$.

\section{Results}

Figure 1 details the results of one experiment examining the effects of electroporation of sucrose buffer on the induction of CAT expression driven by 
HIV-LTR. In this experiment, cells were exposed to differing electric voltage levels $(0.1$ or $0.3 \mathrm{kV})$ in phosphate-buffered sucrose. At the same time, each culture was monitored for the number of total viable cells when the total number of input cells for each experimental group was the same. These results demonstrated maximal induction of the LTR-CAT construct at voltages which resulted in maximal cell killing. It should be noted that equal numbers of viable cells only were used for each CAT assay so as to avoid variation caused by the number of dead cells resulting from the treatment conditions. These and all other results are from a single experiment since cpm are not directly comparable from one experiment to the next; all results have been repeated twice after the original observation to confirm validity.

Next, the effects of UV exposure on expression of the CAT reporter gene were examined; Fig. 2 shows results demonstrating induction of CAT following UV exposure. The response peaked at $24 \mathrm{~h}$ following exposure and was maintained at high levels even as late as $72 \mathrm{~h}$ following exposure; conditions were such that cell death was induced. Again, it should be noted that in these experiments, equal numbers of viable cells were used in determining the number of cells to be used in each CAT assay. The fact that this response remains high in those cultures in which cell death had been triggered, but not in sublethally treated cultures, further supports the concept that induction of HIV-LTR is associated with cell death rather than with DNA damage.

Figure 3 demonstrates the results of experiments examining UV effects 
on both colony formation (14-day assay) and CAT expression in the same cell cultures. Cellular colony formation was used as a measure of cell division/propagation capability. These experiments demonstrate a correlative relationship between HIV-LTR-mediated CAT expression and the lack of cell survival following UV exposure, i.e., cells that are not able to go on to divide express higher levels of LTR-CAT than those that do go on to divide. Fig. 4 similarly examines the effects of multiple UV doses on HIV-LTR-CAT induction. Exposures of $5 \mathrm{~J} / \mathrm{m}^{2}$ were not additive, and a dose between 5 and $20 \mathrm{~J} / \mathrm{m}^{2}$ was required for induction of HIV-LTR. These results suggest that HIV-LTR has a threshold UV dose for induction of CAT and that this threshold dose corresponds to a dose at which cell killing is first detectable in these cultures.

Table 1 summarizes the results of a series of experiments from our own published and unpublished work $(4,7)$ in which various agents were tested under different conditions for their abilities to induce HIV-LTR-CAT expression using the stably transfected cell line reported here. Experiments from this manuscript are included in these results but reflect only a partial collection of results reported in Table 1 . These experiments demonstrated that treatments which reduced cell survival in a 14-day colony forming cell assay also induced CAT expression. Treatments which induced HIV-LTR-mediated CAT expression included low $\mathrm{pH}$ (6.4), high pH (8.4), electroporation, UV exposure (dosedependent), cisplatin, methotrexate, and excess heat (700 W [microwave] for 
$10 \mathrm{~s}$ in a small volume of PBS). On the other hand, treatments which had no effect on viability and no effect on HIV-LTR-CAT induction included co-culture with metronidazole (a DNA-damage-inducing drug), vitamin $\mathrm{C}$ treatment, microwave exposure in an excess volume of medium to reduce overheating, exposure to electromagnetic fields, heat-shock $\left(10 \mathrm{~min}\right.$ at $43^{\circ} \mathrm{C}, 2 \mathrm{~h}$ at $39^{\circ} \mathrm{C}$, solar radiation, sulindac, and salicylic acid. Other work from our group has documented a failure to induce HIV following $\gamma$-ray exposure (7) and following nutrient arrest (Table 1). This suggests that not all methods of inducing cell death are efficient in inducing HIV.

\section{Discussion}

These results suggest a potentially causative association between some forms of cell killing and the induction of HIV expression. Past work has shown the requirement for new protein synthesis for induction of HIV (8). We hypothesize that one pathway for inducing cellular death (apoptosis or programmed cell death), which also requires new protein synthesis $(9,10)$, causes induction of HIV expression. The fact that this response is not repressed within the first 72 $h$ following UV exposure (Fig. 2) suggests that the HIV inductive response is not capable of being directly repressed by the dying cell.

We propose a model whereby HIV lays dormant in cellular DNA until apoptosis or cell death is naturally induced; this activation of apoptosis then 
turns on HIV expression so that maximal viral transcription occurs in apoptotic cells. Much work has demonstrated a relationship between HIV and apoptosis $(8,11-13)$, with most observations suggesting that HIV itself induces the apoptotic process. Our cell system does not produce active virus, so we cannot examine the possibility that HIV itself induces apoptosis, as shown by others $(8,11-13)$. Our data suggest, however, that the cell death/apoptotic response induces HIV. This could explain why HIV is expressed in vivo most commonly in $\mathrm{T}$ cells which undergo natural developmental apoptosis in adults.

Past work has also suggested that UV-induced HIV transcription is mediated directly by DNA damage (8). Our model proposes that one mechanism by which HIV is induced is as a consequence of a cell death response; this response can be induced by a variety of agents, including those which damage DNA (UV, neutrons), those which denature proteins (excess heat; $\mathrm{pH}$ variations), and those which disrupt cell signaling (electroporation). The actual intracellular signal that induces programmed cell death responses is not known but may provide important insights for studies of HIV gene regulation. It is interesting that $\gamma$-rays have no effect on HIV expression in HeLa cells, a cell line which does not induce functional p53 protein following $\gamma$ ray exposure due to presence of the papillomavirus protein E6. HIV induction may be associated with a p53-dependent pathway of cell death/apoptosis. In addition, recent work has demonstrated a requirement for NF-kB in HIV-LTR induction (14). The relationship of NF-kB to p53/apoptosis pathways is not 
yet clearly established buy may play a significant role in the DNA damage response of the HIV-LTR.

\section{Acknowledgements}

The authors wish to thank Kay Bexson for excellent secretarial assistance and Gordon Holmblad for assistance in irradiations.

Work supported by the U.S. Department of Energy, Office of Health and Environmental Research, under Contract No. W-31-109-ENG-38. 


\section{References}

1. Valerie, K., A. Delers, C. Bruck, C. Thiriart, H. Rosenberg, C. Debouck, and M. Rosenberg. 1988. Activation of human immunodeficiency virus type 1 by DNA damage in human cells. Nature. 333:78-81.

2. Morrey, J.D., S.M. Bourn, T.D. Bunch, M.K. Jackson, R.W. Sidwell, L.R Barrows, R.A. Daynes, and C.A. Rosen. 1991. In vivo activation of human immunodeficiency virus type 1 long terminal repeat by UV type A (UVA) light plus psoralen and UVB light in the skin of transgenic mice. J. Virol. 65:5045-5051.

3. Valerie, K., and M. Rosenberg. 1990. Chromatin structure implicated in activation of HIV-1 gene expression by ultraviolet light. New Biology. 2:712-718.

4. Woloschak, G. E., C.-M. Chang-Liu, J. Panozzo, and C.R. Libertin. 1994. Low doses of neutrons induce changes in gene expression. Radiat. Res. 138:S56-S59.

5. Yamagol, S., T. Kohda, and M. Oishi. 1991. Poly (ADP-ribose) 
polymerase inhibitors suppress UV-induced human immunodeficiency virus type 1 gene expression at the post transcriptional level. Molec. Cell. Biol. 11:3522-3527.

6. Zmudzka, B.S., and J.Z. Beer. 1990. Activation of human immunodeficiency virus by ultraviolet radiation. Photochem. Photobiol. 52:1153-1162.

7. Libertin, C.R., J. Panozzo, K. Groh, C.-M. Chang-Liu, S. Schreck, and G.E. Woloschak. 1995. Effects of gamma rays, ultraviolet radiation, sunlight, microwaves, and electromagnetic fields on gene expression mediated by human immunodeficiency virus promoter. Radiat. Res. In press.

8. Stein, B., M. Kramer, H.H. Rahmsdorf, H. Ponta, and P. Herrlich. 1989. UV-induced transcription from the human immunodeficiency virus type 1 (HIV) long terminal repeat and UV-induced secretion of an extracellular factor that induces HIV-a transcription in irradiated cells. J. Virol 63:4540-4544.

9. Inouye, M., M. Tamaru, and Y. Kameyama. 1992. Effects of cycloheximide and actinomycin D on radiation-induced apoptotic cell 
death in the developing mouse cerebellum. Int. J. Radiat. Biol. 61:669674.

10. Sellins, K.S., and J.J. Cohen. 1987. Gene induction by $\gamma$-irradiation leads to DNA fragmentation in lymphocytes. J. ImmunoL 139:31993206.

11. Laurent, A.G., B. Krust, S. Muller, Y. Riviere, M.-A. Rey-Cuille, J.-M. Bechet, L. Montagnier, and A.G. Hovanessian. 1991. The cytopathic effect of HIV is associated with apoptosis. Virology. 185:829-839.

12. Meyaard, L., S.A. Otto, R.R. Jonker, M.J. Mijnster, R.P.M. Keet, and F. Miedema. 1992. Programmed death of T cells in HIV-1 infection. Science. 257:217-219.

13. Terai, C., R.S. Kornbluth, C.D. Pauza, D.D. Richman, and D.A. Carson. 1991. Apoptosis as a mechanism of cell death in cultured T lymphoblasts acutely infected with HIV-1. J. Clin. Invest. 87:17101715.

14. Kopp, E., and S. Ghosh. 1994. Inhibition of NF-kB by Sodium Salicylate and Aspirin. Science. 265:956-959. 


\section{Figure Legends}

Figure 1. A: Cell survival documents the numbers of viable cells remaining in the culture as determined by trypan blue dye exclusion at the time of cell harvest. The number atop each column indicates the percentage of viable cells remaining in the culture. B: Equal numbers of viable cells were counted and used in the CAT assays for the ${ }^{3} \mathrm{H}$ acetylation of chioramphenicol. Assays were performed as described previously (10).

Figure 2. HeLa cells stably transfected with the HIV-LTR-CAT construct were exposed to different doses (as indicated) of UVC $(254 \mathrm{~nm})$ germicidal lamp. Cells were harvested $24-180 \mathrm{~h}$ following exposure. Equal numbers of viable cells were used in each CAT assay (10). At the high dose $\left(25 \mathrm{~J} / \mathrm{m}^{2}\right)$, there were no viable cells remaining for assay after $96 \mathrm{~h}$ post-exposure.

Figure 3. HeLa cells stably transfected with HIV-LTR-CAT construct were exposed to doses $\left(\mathrm{J} / \mathrm{m}^{2}\right)$ as indicated of UVC $(254 \mathrm{~nm})$ germicidal lamp. From each culture, an equal number of cells for each treatment were used for 14-day colony assays for cell survival determination (A; expressed as the number of colonies/number of cells plated $\times 100$ ) and equal numbers of viable cells were set up in CAT assays for expression studies $(B ; 10)$. 
Figure 4. HeLa cells stably transfected with HIV-LTR-CAT were exposed at 24-h intervals to 0,5 or $10 \mathrm{Jm}^{-2}$ UVC (254 nm) germicidal lamp. Cells were harvested at $24 \mathrm{~h}$ and $48 \mathrm{~h}$ post-exposure. Equal numbers of viable cells were used for CAT assays as described (10). 
Table 1. Effects of Various Agents on HIV-LTR-CAT Induction

\begin{tabular}{|c|c|c|c|}
\hline Agent & $\begin{array}{l}\text { Fold HIV-LTR- } \\
\text { CAT Induction }\end{array}$ & $\begin{array}{l}\text { No. } \\
\text { Experi- } \\
\text { ments }\end{array}$ & $\begin{array}{l}\Delta \text { Cell } \\
\text { survi- } \\
\text { valc }\end{array}$ \\
\hline No treatment & 1.0 & $>20$ & 0 \\
\hline $\mathrm{pH} 6.7-8.1$ & $0.7-1.0$ & 3 & 0 \\
\hline $\mathrm{pH} \quad 6.4$ & $1.5-2.0^{\mathrm{b}}$ & 2 & $\downarrow$ \\
\hline $\mathrm{pH} 8.4$ & $1.6-2.0^{\mathrm{b}}$ & 3 & $\downarrow$ \\
\hline $\begin{array}{l}\text { Microwaves }(700 \mathrm{~W}), 5-12 \mathrm{~s}, 25 \mathrm{ml} \\
\left.\mathrm{PBS} / \text { pen/strep (temp. }<43^{\circ} \mathrm{C}\right)\end{array}$ & $0.8-1.1$ & 4 & 0 \\
\hline $\begin{array}{l}\text { Microwaves }(700 \mathrm{~W}), 10 \mathrm{~s}, 10 \mathrm{ml} \\
\left.\mathrm{PBS} / \text { pen/strep (temp. } \angle 43^{\circ} \mathrm{C}\right)\end{array}$ & $2 \cdot 2-2 \cdot 5^{b}$ & 4 & $\downarrow$ \\
\hline Electromagnetic radiation $(60 \mathrm{~Hz})$ & $1.0-1.2$ & 4 & 0 \\
\hline $\begin{array}{l}\text { Ultraviolet radiation }\left(\geq 5 \mathrm{~J} / \mathrm{m}^{2} 2.5\right. \\
\left.\mathrm{J} / \mathrm{m}^{2} / \mathrm{s}\right)\end{array}$ & $2.0-29.2^{b}$ & $>20$ & $\downarrow$ \\
\hline $\begin{array}{l}\text { Ultraviolet radiation }\left(<2.5 \mathrm{~J} / \mathrm{m}^{2}\right. \\
\left.2.5 \mathrm{~J} / \mathrm{m}^{2} / \mathrm{s}\right)\end{array}$ & $1.0-1.3$ & $>20$ & $\downarrow$ \\
\hline vitamin $\mathrm{C}(0.1-1.0 \mathrm{mg} / \mathrm{ml})$ & $0.8-1.2$ & 2 & 0 \\
\hline Metronidazole $(6-12 \mu \mathrm{g} / \mathrm{ml})$ & $0.8-1.3$ & 2 & 0 \\
\hline $\begin{array}{l}\text { Electroporation of buffered } \\
\text { sucrose }(0.1-0.3 \mathrm{kV})\end{array}$ & $3.7-36.1^{b}$ & 3 & $\downarrow$ \\
\hline $\begin{array}{l}\text { Heat shock }\left(38-45^{\circ} \mathrm{C}, 10 \mathrm{~min} ; 39^{\circ} \mathrm{C} \text {, }\right. \\
2 \mathrm{~h})\end{array}$ & $0.7-1.1$ & 3 & 0 \\
\hline $\begin{array}{l}\text { Fission-spectrum neutrons ( } 48 \mathrm{CGY} \text {, } \\
12 \mathrm{cGy} / \mathrm{min} \text { ) }\end{array}$ & $1.2-2.0^{b}$ & 3 & $\downarrow$ \\
\hline Solar radiation $\left(240 \mathrm{KJ} / \mathrm{m}^{2}\right)$ & $1.0-1.3$ & 3 & 0 \\
\hline Sulindac $(.72-72 \mu \mathrm{g} / \mathrm{mL})$ & $0.7-.09$ & 2 & $N / D$ \\
\hline Cisplatin $(50 \mu \mathrm{M})$ & $12-12 \cdot 5^{b}$ & 6 & $\downarrow$ \\
\hline Methotrexate $(12 \mu \mathrm{M})(3-8 \mathrm{~d})$ & $4-15^{b}$ & 4 & $\downarrow$ \\
\hline DMSO $(.001-.1 \mathrm{M})$ & $4.1-6$ & 10 & $\mathrm{~N} / \mathrm{D}$ \\
\hline IL2 $(10,000 \mathrm{U} / \mathrm{mL})$ & 1.0 & 2 & $\mathrm{~N} / \mathrm{D}$ \\
\hline$\gamma$-IFN $(500 \mathrm{U} / \mathrm{mL})$ & $0.8-1.0$ & 2 & $\mathrm{~N} / \mathrm{D}$ \\
\hline $\begin{array}{l}\gamma \text { rays }(20-600 \text { cGy dose. } \\
1-50 \text { cGy/min dose-rate) }\end{array}$ & $0.9-1.1$ & $>20$ & $N / D$ \\
\hline Salicylic acid $(0.125-12.5 \mathrm{mM})$ & 1.0 & 5 & 0 \\
\hline $.05 \%$ serum (nutrient arrest) $(7 \mathrm{~d})$ & $0.5^{\mathrm{b}}$ & 3 & $\downarrow$ \\
\hline $\mathrm{TPA} \quad(50 \mathrm{ng} / \mathrm{ml}-25 \mu \mathrm{g} / \mathrm{ml})$ & $1.5-2.5^{\mathrm{b}}$ & 3 & $\mathrm{~N} / \mathrm{D}$ \\
\hline
\end{tabular}

${ }^{a}$ All measurements $12-24 \mathrm{~h}$ following exposure except as noted.

${ }^{\mathrm{b}} \mathrm{Significantly}$ different from controls at $\mathrm{p}<.01$.

${ }^{c}$ Change in cell survival as measured in a 14-day colony assay; $N D=$ not done; $0=$ No change; $\downarrow=$ drop in survival by 258 or more. 


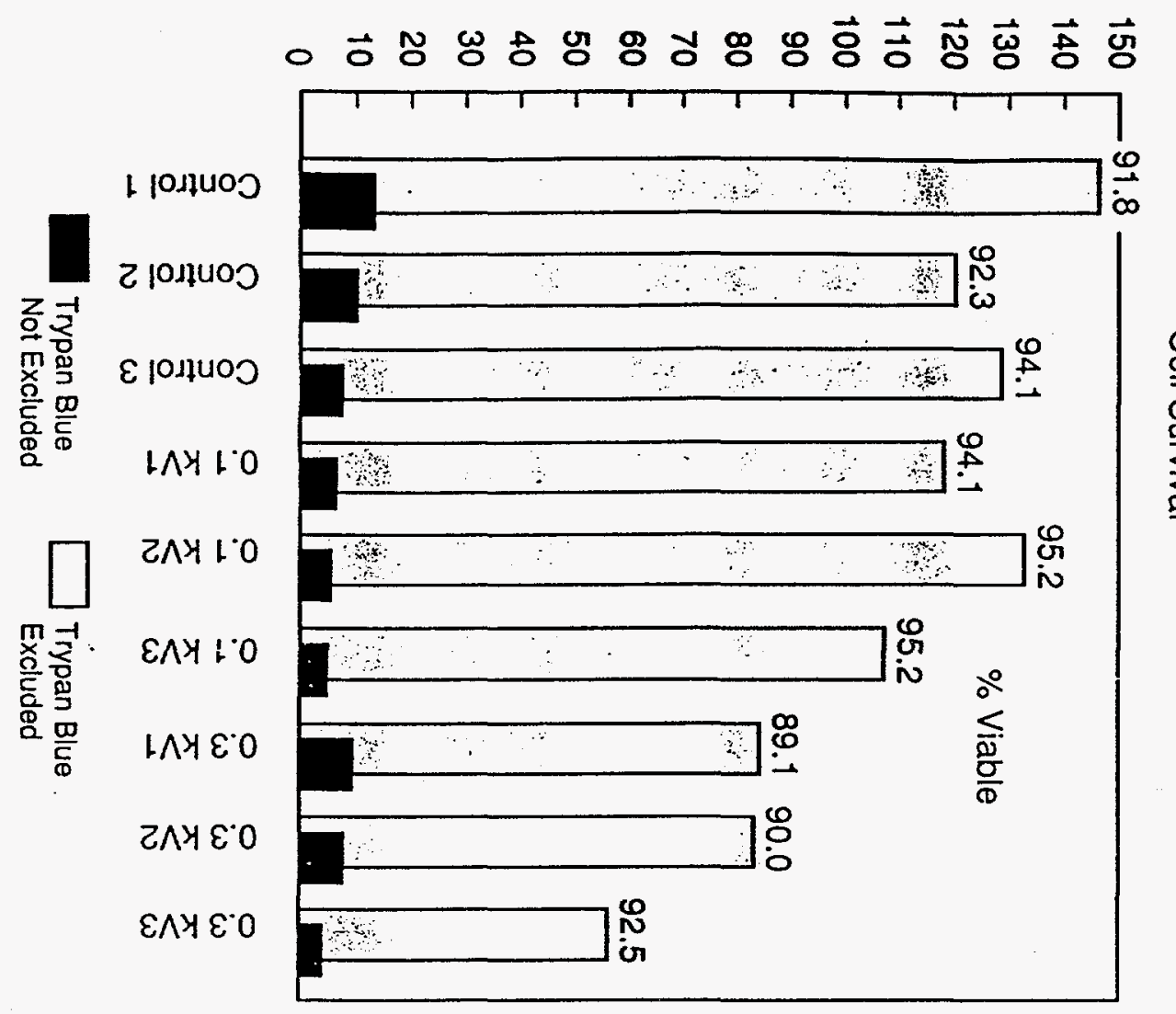

寓

CPM CHLORAMPHENIICOL-3H

$\frac{5}{5}$

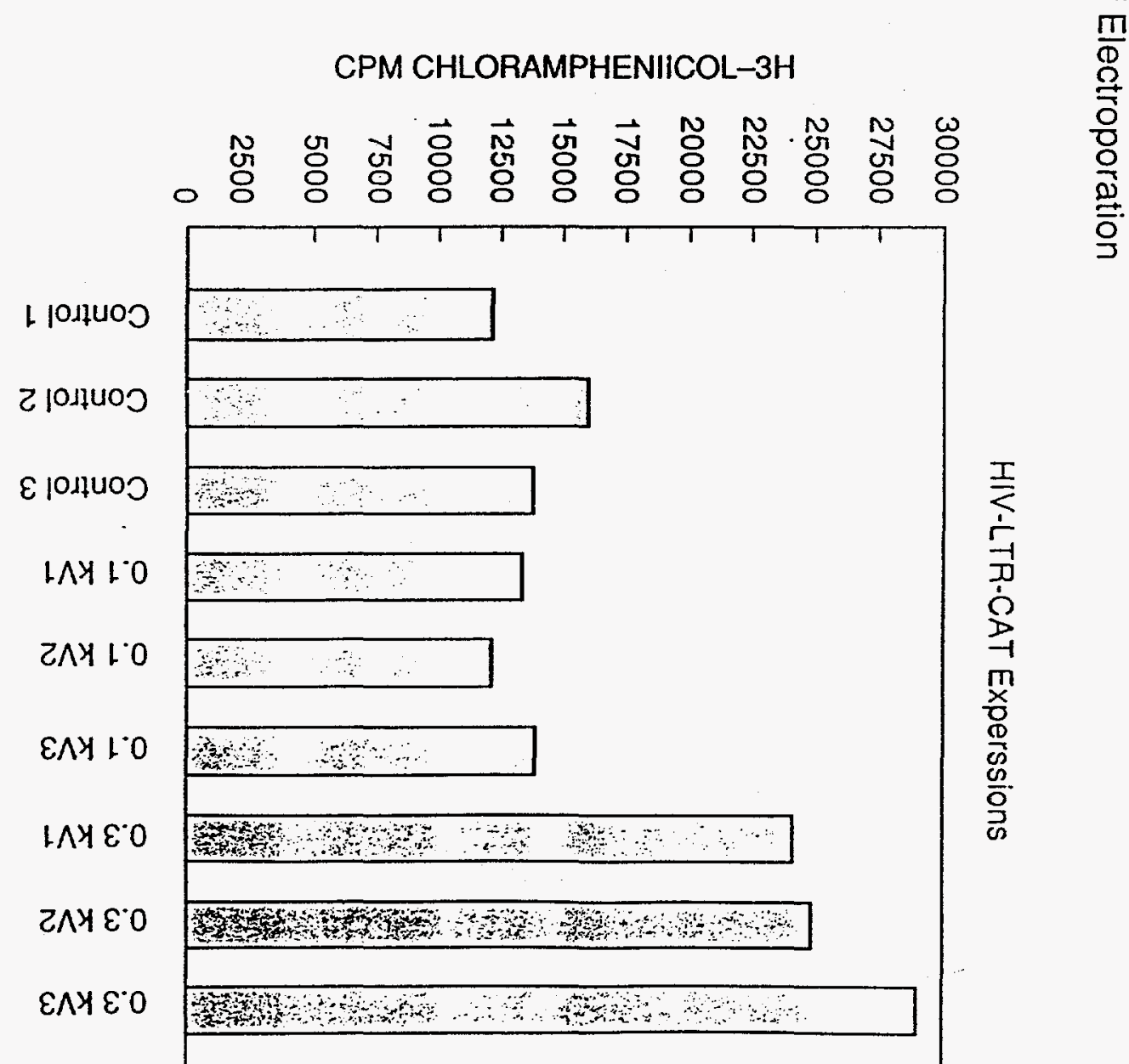


HIV-LTR Expression

Following UV Irradiation

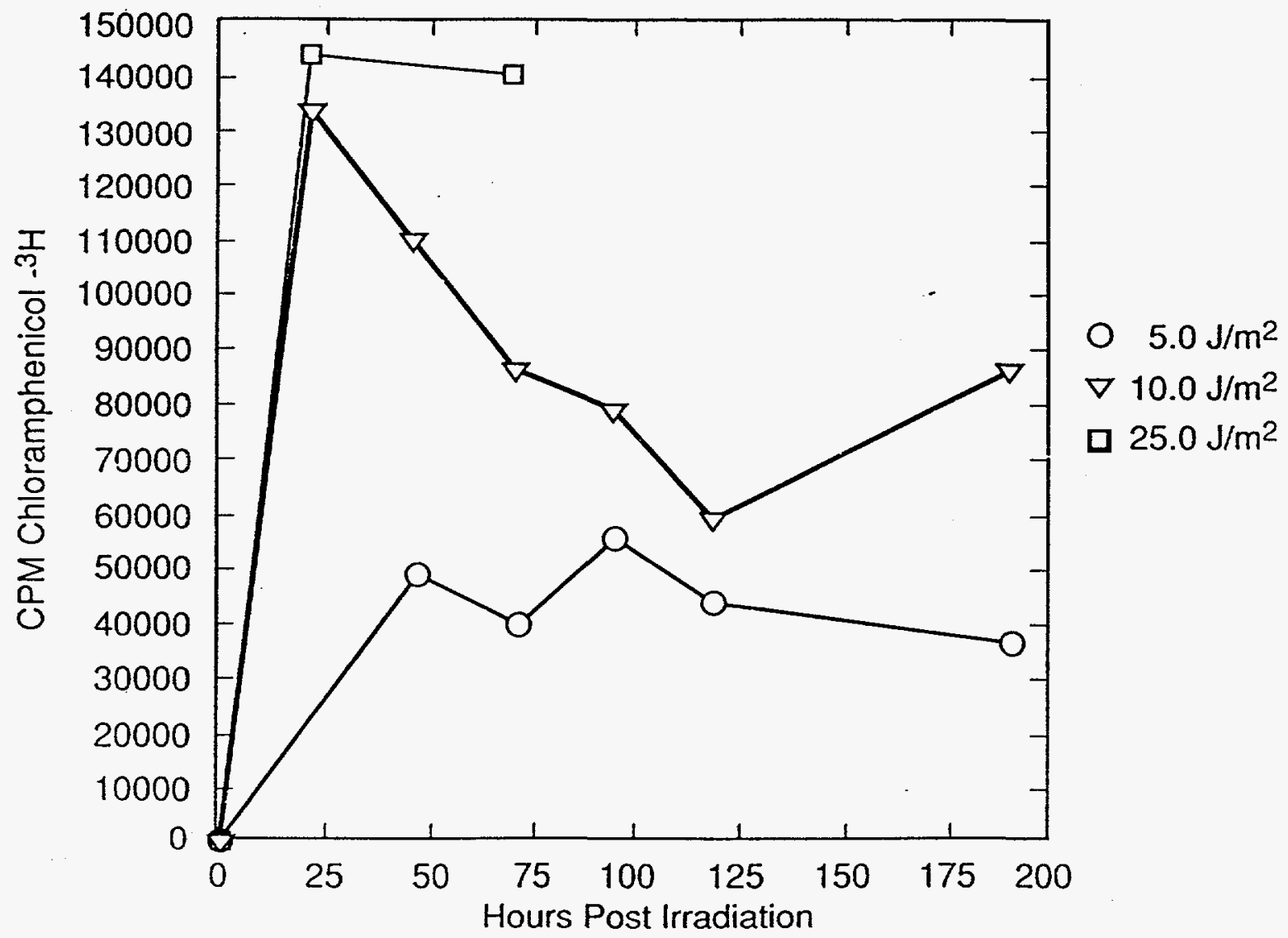

Figure 2 
CPM Chloramphenicol-3H
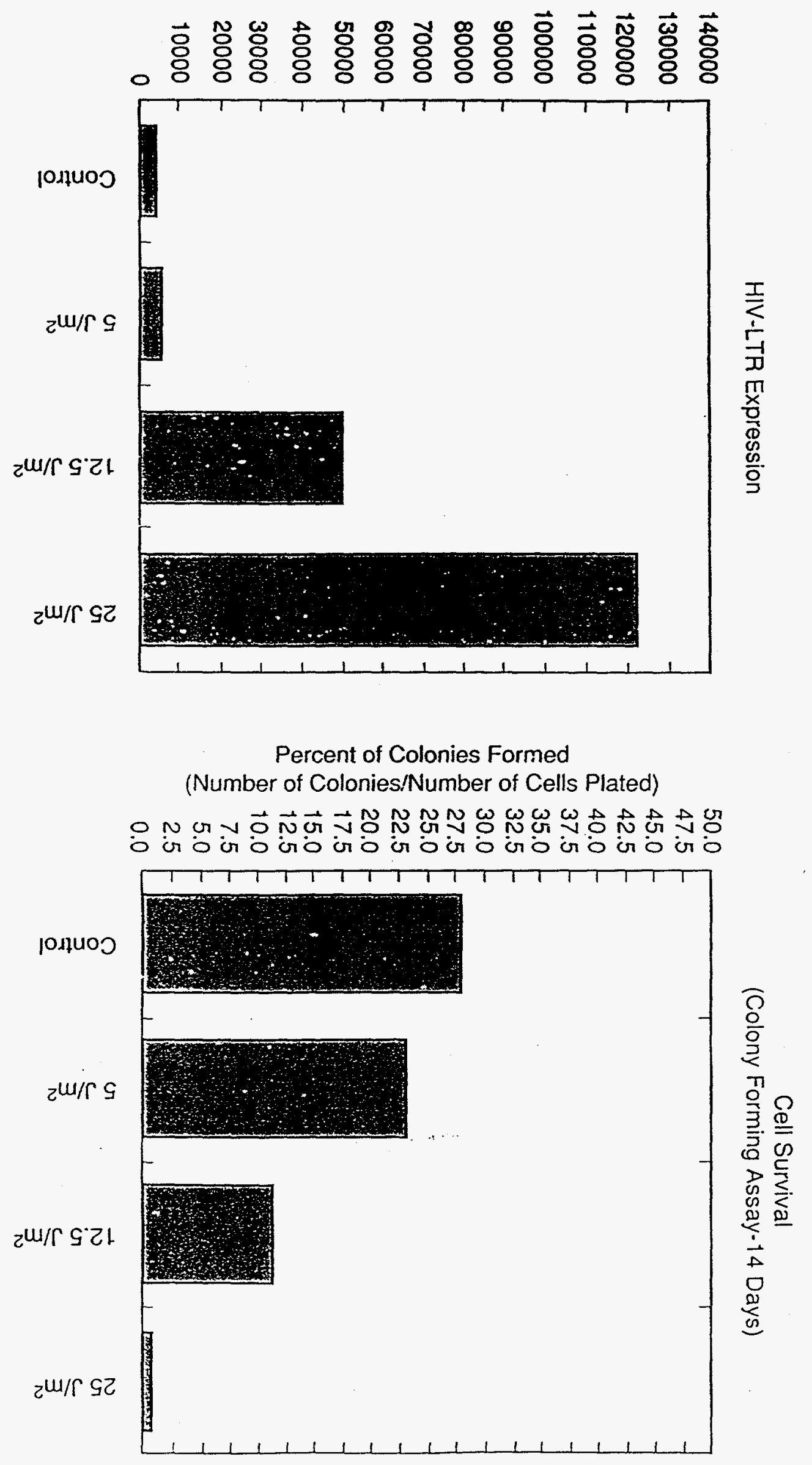

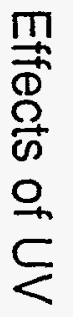


Effects of Ultraviolet Radiation on

HIV-LTR Expression

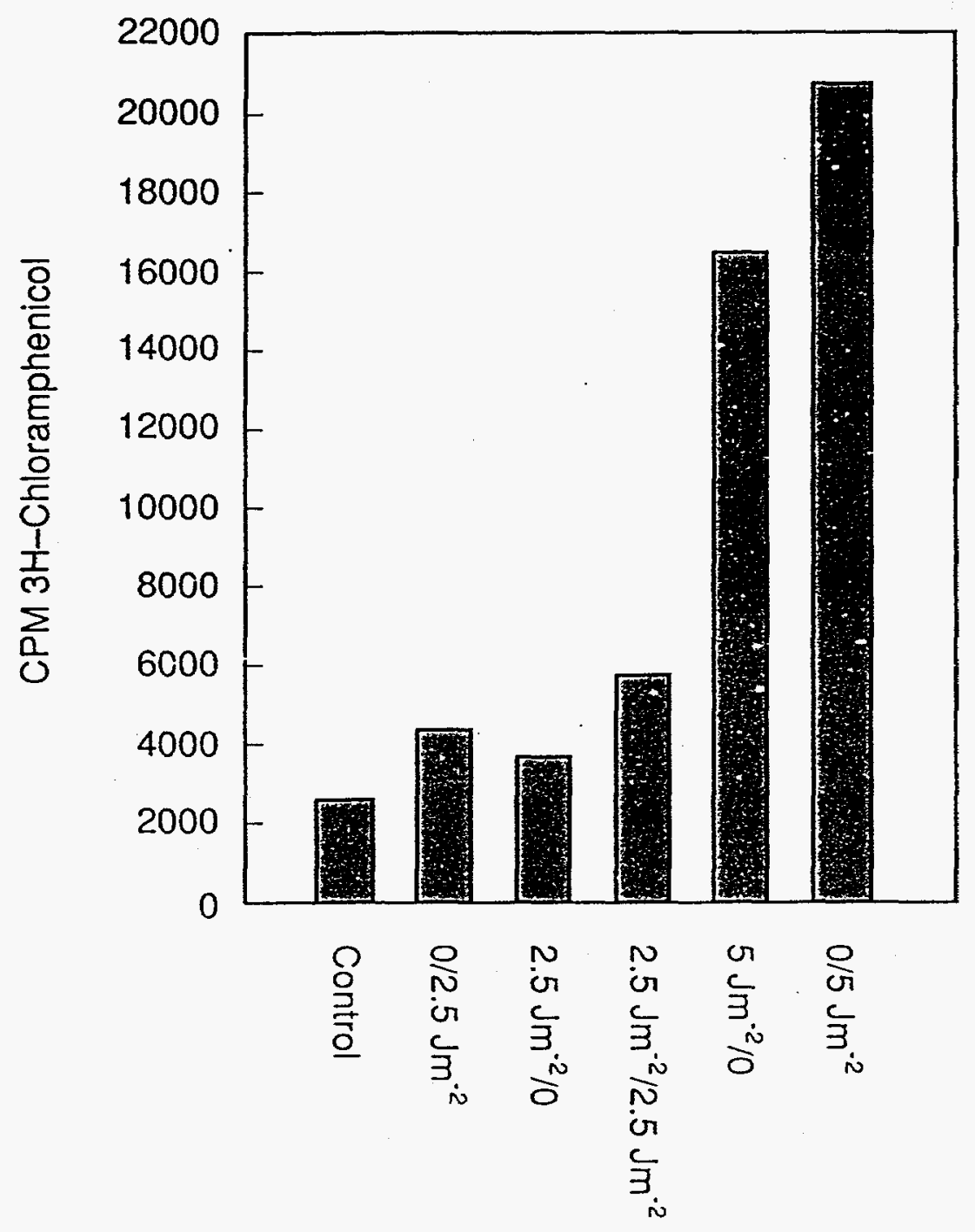

Figuae 4 